\title{
Spatio Temporal Evaluation of Vegetation Cover in Sargodha (Pakistan) for Sustainable Urban Future
}

\author{
By Omar Riaz ${ }^{*}$, Huma Munawar', Maryam Khalid ${ }^{2}$
}

\begin{abstract}
The monitoring of global vegetation through SRS (satellite remote sensing) data is central part of sustainable urban development and regional planning which is handy to improve our knowledge regarding spatial and temporal patterns and traits of vegetation in any area. In recent years rapid urbanization has converted Sargodha into $5^{\text {th }}$ largest city of the Punjab which resulted in change and modification of urban morphology and invited the attention of researchers to investigate, analyze and evaluate the type, length and conditions of plant life. In this work an attempt was made to examine spatio temporal dynamics of vegetation cover in Sargodha by integration with multi temporal satellite images and GIS. The research shows the applicability of Landsat images for the evaluation of vegetation exchange between the years of 1992-2015. The findings of the study indicated that during the past 24 years, a dramatic change took place in reduction of greenness because of rapid increase in population distribution and density, urban development and other infrastructural development. The results highlighted the importance of NDVI for better effects concerning accuracy to evaluate the vegetation cover.
\end{abstract}

Keywords: Urban expansion, Image processing, Vegetation cover, NDVI, Change Detection

\section{Introduction}

Urbanization (the conversion of land settlements from rural to urban areas) is global phenomena which is taking place with rapid rates than ever before. During the last decades of $20^{\text {th }}$ century urban growth and urbanization has been considered a symbol of developing countries of the world (Alsaaideh et al., 2011). United Nations examined that Approximately 54\% of world population was urbanized in 2014 and projected to increase $66 \%$ in 2025 (UN, 2014). All the expected urban growth in the world will take place in less developed countries of Asia and Africa whose urban population is expected to increase from 2.7 billion to 5.1 billion between the time periods of $2011-2050$ (UN, 2011). Pakistan, like many other developing countries of the world, has experienced an explosive growth rate in various years which increased the proportion of urban population in Pakistan. Pakistan possesses the highest proportion of urban population among other South Asian countries which increased from 17.8\% in 1951 to 32.5\% in 1998. At present, about $40 \%$ of population of Pakistan is living in cities.

With urban expansion land is exposed to negative changes which possess several problems such as urban slums, traffic congestion, environmental pollutions, loss of biodiversity, poor water and air quality and climate change (Ellis and Pontius, 2006). Rapid urban development and associated land use changes have been witnessed in developing countries especially in Asia and Africa (United Nation, 2011). Urban land use /land cover change and vegetation loss detection through satellite data is central part of

${ }^{1}$ Department of Earth Sciences, University of Sargodha, Pakistan

2Department of Geography, G. C University, Faisalabad, Pakistan

* Corresponding Author 
sustainable urban development and regional planning (Rimal, 2010; Riaz et al, 2014). Urban flora plays an ample position in moderating the affects of heat island, discount of noise pollution as well as the industrial importance and power needs (Matteucci and Morello, 2009 ; Arulbalaji et al., 2014). The metropolis's vegetation is an important feature which go under changes due to urban development and multiplied the ratio of land use / land cover alternation, confined land for agricultural, commercial, socio monetary improvement and make the issue of land use / land cover change extra prominent (Bhalli et al., 2013).

Sargodha remained rich in greenery throughout the course of history. The introduction of canal irrigation system in 1903 when lower Jhelum Canal at Rasul was opened in the area brought green revolution in this region. After Independence in 1947, due to settlements, urbanization and other infrastructure development most of the trees were cut leaving a small proportion of bushes and trees within the city (GOP, 1999).

For the monitoring of spatial aspects of the city development, reliable sources of information are of key importance. The multi-spectral and multi-temporal remotely sensed information integrated with techniques of geo informatics offer adequate facts to have a look at spatial sample of city growth and land use adjustments (Perse et al., 1995). However, in 1972, after the launch of first far off sensing satellite the low cost and easily availability of satellite images made it possible to detect, analyze and display city expansion and related land use modifications and altered the conventional techniques (Marriappan et al., 2010). These strategies are taken into consideration as one of the important, excellent and useful tools for urban sprawl and land use, vegetation cover changes ( Sultana and Marzen, 2004; Lillesened et al., 2004). Present study is centered to identify the spatial distribution of vegetation cover and to assess Spatio- Temporal changes of vegetation in Sargodha on the subject of city expansion since 1992.

\section{Study Area}

The study is conducted in Sargodha (Pakistan) which is situated in central Punjab about 172 kilometers northwest of Lahore. Sargodha is $5^{\text {th }}$ largest city of the Punjab province that lies between $31^{\circ} 34^{\circ}$ to $32^{\circ} 36^{\circ}$ North latitudes and $72^{\circ} 10^{`}$ to $73^{\circ}$ $18^{`}$ East longitudes with an average elevation of 607 feet above sea level. Total area of Sargodha district is 5854 square kilometers (GOP, 1999). According to 1998 census of Pakistan, total population of Sargodha was about 2.6 million with population density of 455 persons per square kilometer. Urban population was 0.864 million which constitute $28 \%$ of urban population of the district (GOP, 1999). The latest studies show that the population of Sargodha has increased about 3.3 million (Khalid, 2013). According to the Punjab Development Statistics estimates of 2015 urban population of Tehsil Sargodha was 1,422,000 and 584,000 persons were living in urban area. The land of Sargodha is covered with alluviums called Karana bars which are the part of West Indus Basin, deposited by Indus River and its tributaries in Precambrian age of geological period (GOP, 1999). Like many other cities of Pakistan, Sargodha has continental type of climate very hot in summer to cool in winter (GOP, 1999). 


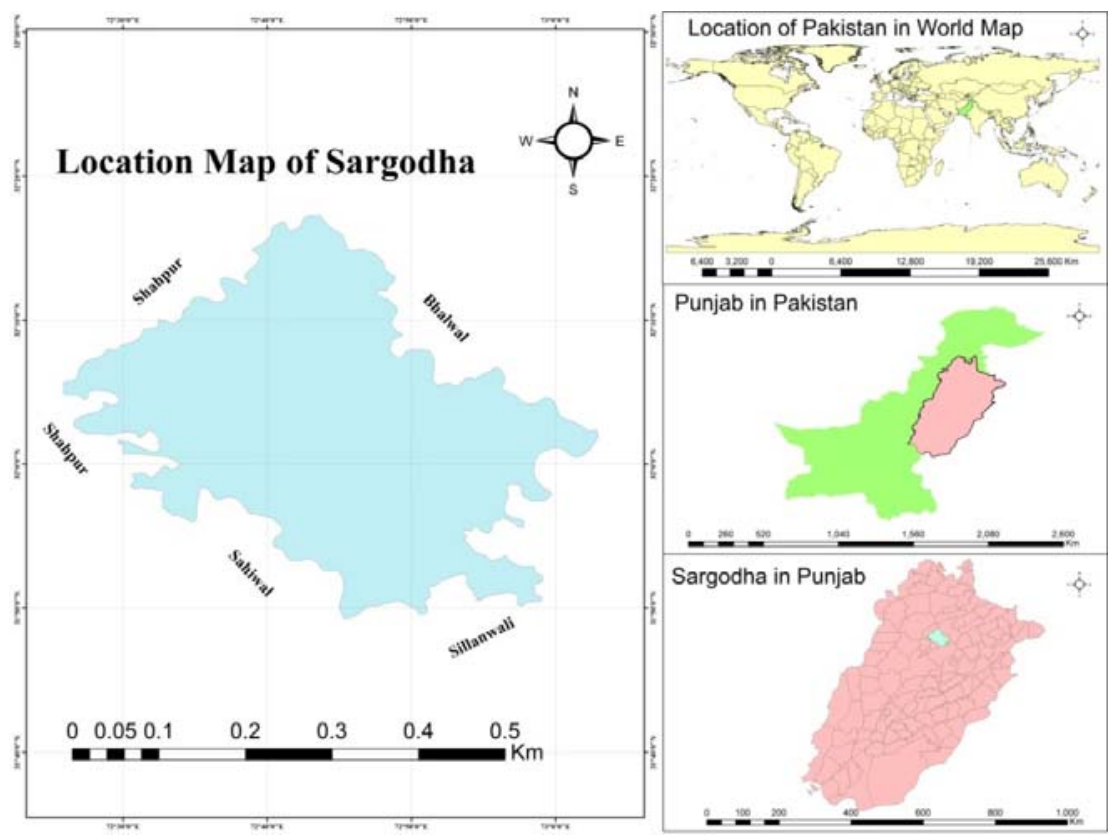

Fig.1: Location Map of Study Area.

\section{Materials \& Methods}

In order to examine vegetation cover conditions of Sargodha city in relation to urban expansion since 1992, five Landsat TM and ETM+ images were acquired for the years 1992, 2000, 2005, 2010 and 2015. These images were obtained from United States Geological Survey (USGS) and Global Land Cover Facility (GLCF). The characteristics of satellite images are presented in

Table 1: Characteristics of Satellite Images

\begin{tabular}{|c|c|c|c|c|c|}
\hline Year & $\begin{array}{c}\text { Date of } \\
\text { Acquisition }\end{array}$ & Satellite Sensor & $\begin{array}{c}\text { Spatial } \\
\text { Resolution }\end{array}$ & Path/Row & $\begin{array}{c}\text { Spectral Resolution } \\
\text { (Bands) }\end{array}$ \\
\hline 1992 & $20-09-1992$ & Landsat TM & $30 \mathrm{~m}$ & $150 / 37$ & 7 \\
\hline 2000 & $16-10-2000$ & Landsat ETM+ & $15 \mathrm{~m}$ & $149 / 39$ & 9 \\
\hline 2005 & $02-04-2005$ & Landsat ETM+ & $15 \mathrm{~m}$ & $149 / 39$ & 9 \\
\hline 2010 & $01-01-2010$ & Landsat ETM+ & $30 \mathrm{~m}$ & $150 / 38$ & 9 \\
\hline 2015 & $31-05-2015$ & Landsat8OLI/TIR & $15 \mathrm{~m}$ & $150 / 38$ & 11 \\
\hline
\end{tabular}

Before image processing, Layer stacking, radiometric and geometric correction methods are performed as preprocessing operations. For the production of False Colour Composite (FCC) image different bands of landsat imageries were staked by using Eradas Imagine which combines different individual bands into a single multispectral image file. All the images were than geometrically projected using Universal Traverse Mercator's (UTM) Projection system and World Geodetic System (WGS) 1984 zone $43^{\circ} \mathrm{N}$. Using a well defined boundary of the study area sub- setting of image to clip study 
area and image enhancement were performed in the first stage. These processes were carried out using geospatial tools like ERDAS IMAGINE 13 and Arc Map 10.3 software.

For image classification, four classes were defined which are Agricultural land, Built-up area, Water bodies and others. Ground control points (GCPs) were obtained using a Global Positioning System from locations in relation to the classes of the study area. These GCPs were plotted on landsat images to verify the training sites (defined classes) as regards the spectral signature. Supervised classification for the various classes was performed using maximum likelihood classification. Calculation of NDVI was evaluated for images of 1992, 2000, 2005, 2010 and 2015 by using band 3 (R) and band 4 (NIR) to examine the spatial distribution of vegetation cover and Temporal changes of vegetation. The following equation was employed to determine the NDVI values in an image.

\section{NDVI = (NIR - R) / (NIR + R)}

Or Band 4 - Band 3 / Band $4+$ Band 3

In equation NIR represents near infrared band and $\mathrm{R}$ is red band. NDVI was applied for the landsat images (1992- 2015) to detect the change in vegetation cover. After that NDVI maps of two different years 1992 and 2015 are overlapped to detect the change. Flow chart of study methodology is presented in fig 2.

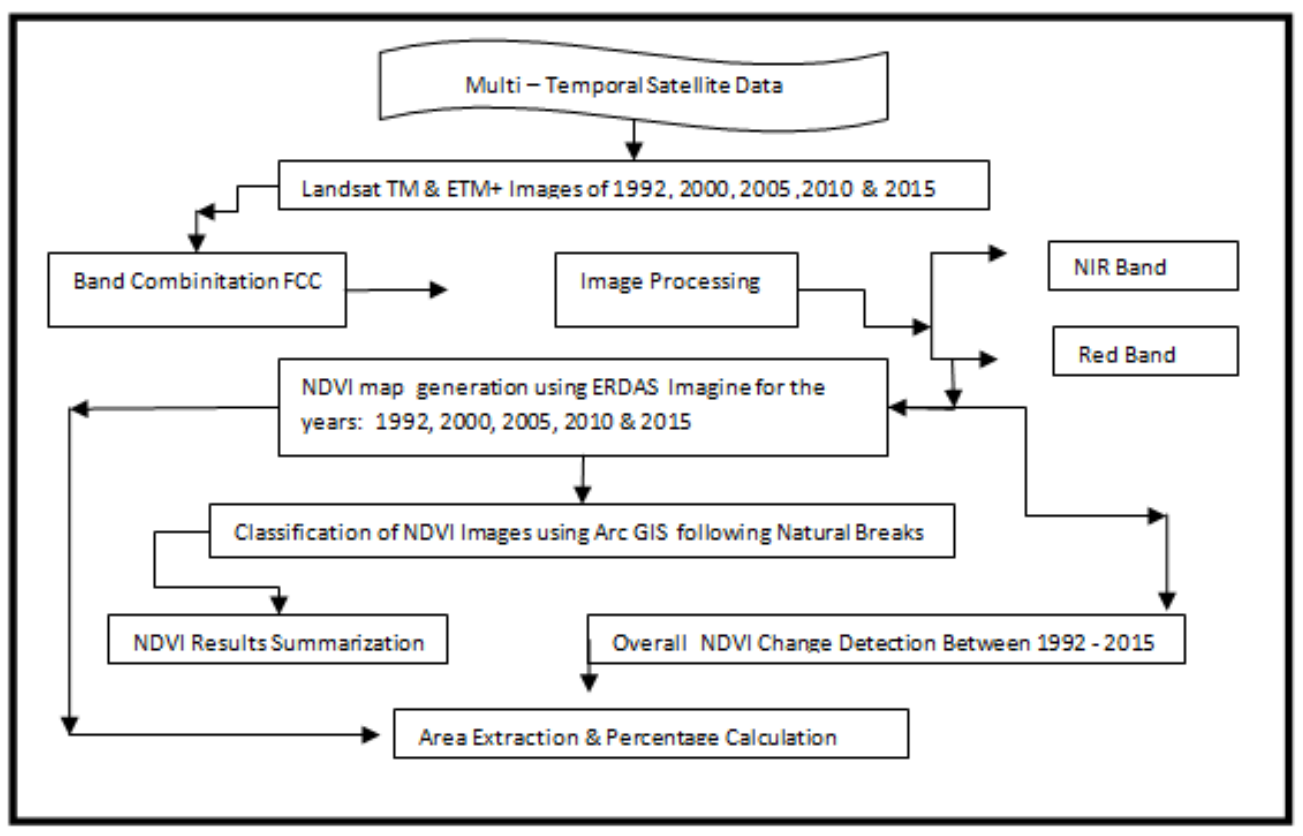

Fig. 2: Flow Chart of Methodology.

\section{Results \& Discussion}

The results of satellite image analysis and discussion on findings (Table 2) showed that the biggest loss of vegetation was observed during the whole study period. 
In current study the maximum and minimum values of NDVI were 0.7 and - 0.04 respectively which were than compared with USGS values. According to the USGS, water bodies, barren and rock surface, Shrub and Grass land, Moderate Green Areas and very green areas are present in Sargodha. From the Figure 3 it can be observed that, during the whole time span of study smallest NDVI values were recorded in urban areas whiles highest NDVI values were recorded in non-urban (vegetated/rural) area.

NDVI maps (1992 - 2015) are shown in Figure 3. Analysis on the Landsat images of Sargodha depicts that in 1992, most of the areas have high vegetation index which revealed the process of urbanization was slow at that time. In 2000, highest vegetation values were observed at city borders while it was low at city center. The NDVI map of 2005 revealed that due to rapid process of urbanization in the region, the areas that have high vegetation in 2000 are converting into little or no vegetation and confined to city peripheries. Small patches of vegetation in forms of parks and grounds in offices and educational institutions were observed in city center. From the maps of 2010 and 2015, it is evident that with the passage of time due to population explosion; urban and infrastructure development, areas of vegetation cover decreased dramatically.

Table 2: Temporal Analysis of Land Cover Changes in Sargodha (1992- 2015).

\begin{tabular}{|c|c|c|c|c|c|c|c|c|c|c|}
\hline \multirow{2}{*}{ year } & \multicolumn{2}{|c|}{$\begin{array}{c}\text { Urban/Built- } \\
\text { up }\end{array}$} & \multicolumn{2}{|c|}{ Agriculture } & \multicolumn{2}{c|}{ Bare Soil } & \multicolumn{2}{c|}{ Water } & \multicolumn{2}{c|}{ Total } \\
\hline & $\begin{array}{c}\text { Area } \\
\mathbf{K m} 2\end{array}$ & $\begin{array}{c}\text { Area } \\
\mathbf{\%}\end{array}$ & $\begin{array}{c}\text { Area } \\
\mathbf{K m} \mathbf{2}\end{array}$ & $\begin{array}{c}\text { Area } \\
\mathbf{\%}\end{array}$ & $\begin{array}{c}\text { Area } \\
\mathbf{K m} \mathbf{2}\end{array}$ & $\begin{array}{c}\text { Area } \\
\mathbf{\%}\end{array}$ & $\begin{array}{c}\text { Area } \\
\mathbf{K m} \mathbf{2}\end{array}$ & $\begin{array}{c}\text { Area } \\
\mathbf{\%}\end{array}$ & $\begin{array}{c}\text { Area } \\
\mathbf{K m} \mathbf{2}\end{array}$ & $\begin{array}{c}\text { Area } \\
\mathbf{\%}\end{array}$ \\
\hline $\mathbf{1 9 9 2}$ & 23.62 & 1.6 & 475.86 & 32.6 & 551.52 & 37.8 & 406 & 27.8 & 1457 & $100 \%$ \\
\hline $\mathbf{2 0 0 0}$ & 55.54 & 3.8 & 657.29 & 45.1 & 730.08 & 50.1 & 14.09 & 0.9 & 1457 & $100 \%$ \\
\hline $\mathbf{2 0 0 5}$ & 83.94 & 5.7 & 643.5 & 44.1 & 714.24 & 49 & 15.32 & 1 & 1457 & $100 \%$ \\
\hline $\mathbf{2 0 1 0}$ & 158.56 & 10.8 & 529.66 & 36.3 & 745.25 & 51.1 & 23.53 & 1.6 & 1457 & $100 \%$ \\
\hline $\mathbf{2 0 1 5}$ & 277.43 & 19 & 365.77 & 25.1 & 646.45 & 44.3 & 167.35 & 11.4 & 1457 & $100 \%$ \\
\hline
\end{tabular}

In terms of the area covered by different types of vegetation, urbanization is observed to be beneficial for shrubs as it showed a boosting trend with land consumption of $20 \%$ in 1992 and $36 \%$ in 2015. The result depicts that during 1992-2015 the overall change in vegetation cover was $-110 \mathrm{~km}^{2}$ and $-7.5 \%$. The urban/built-up area of Sargodha is expanded from $23.62 \mathrm{~km}^{2}$ in 1992 to $277.42 \mathrm{~km}^{2}$ in 2015 . The detailed statistics, image processing results, their graphical representation and visual interpretation revealed the relative vegetation changes occurred in Sargodha. Figure 4 depicts the change in vegetation cover of study area during whole time periods. 


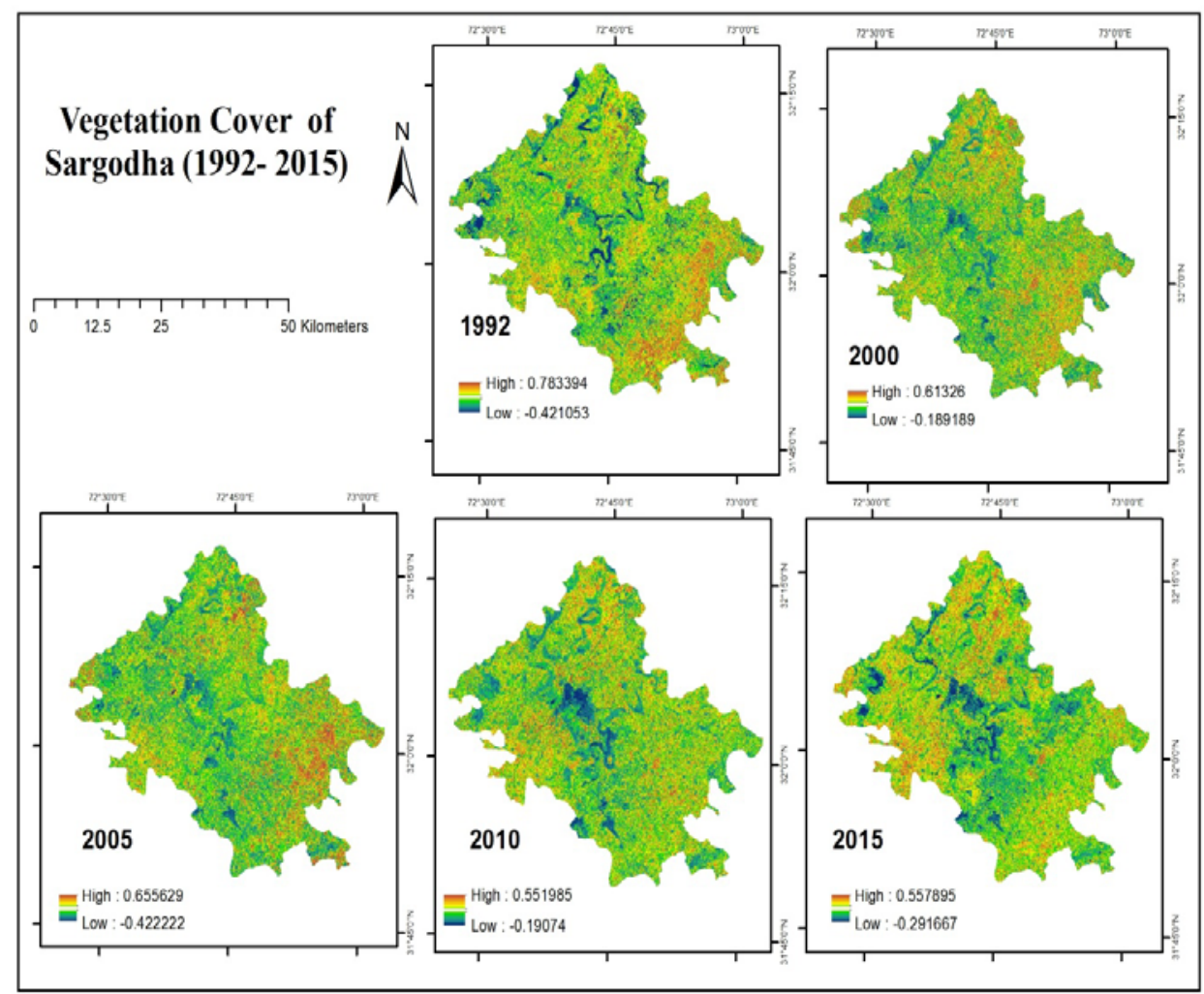

Fig. 3: Vegetation covers of Sargodha (1992 - 2015).

Table 3: Characteristics of various types of vegetation (1992- 2015).

\begin{tabular}{|c|c|c|c|c|c|}
\hline Classes & $\mathbf{1 9 9 2}$ & $\mathbf{2 0 0 0}$ & $\mathbf{2 0 0 5}$ & $\mathbf{2 0 1 0}$ & $\mathbf{2 0 1 5}$ \\
\hline & $\begin{array}{c}\text { Area } \\
\mathbf{\%}\end{array}$ & $\begin{array}{c}\text { Area } \\
\mathbf{\%}\end{array}$ & $\begin{array}{c}\text { Area } \\
\mathbf{\%}\end{array}$ & $\begin{array}{c}\text { Area } \\
\mathbf{\%}\end{array}$ & $\begin{array}{c}\text { Area } \\
\mathbf{\%}\end{array}$ \\
\hline Others/ Mixed use & 61 & 59 & 63 & 62 & 54 \\
\hline Shurbs & 20 & 24 & 21 & 24 & 36 \\
\hline Dense Vegetation & 19 & 17 & 16 & 14 & 10 \\
\hline Total & 100 & 100 & 100 & 100 & 100 \\
\hline
\end{tabular}




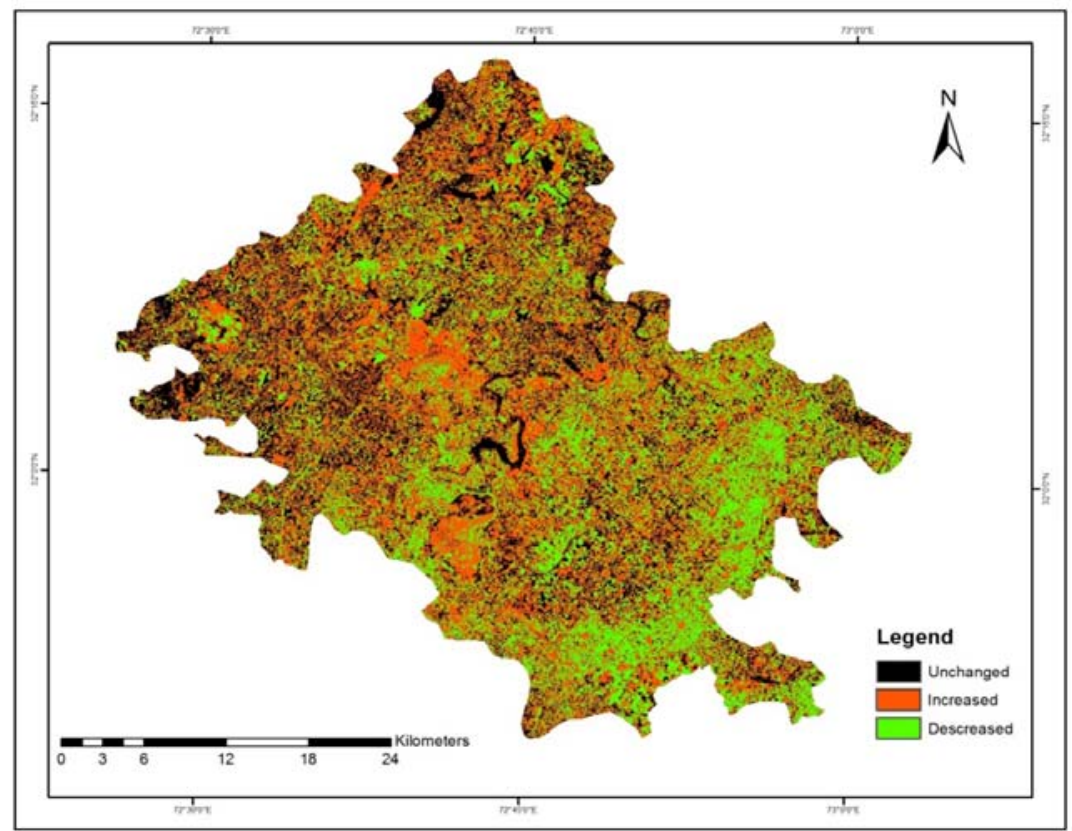

Fig 4: Vegetation Cover Change Detection (1992- 2015).

Temporal pattern of vegetation cover of Sargodha is presented in Fig 3. It was observed that shrubs have increasing trend during the whole time period while dense tree cover show completely negative trend as compare to shrubs which decreased from land consumption of $19 \%$ in 1992 to $10 \%$ in 2015.

\section{Conclusion}

The California of Pakistan has witnessed aerial expansion, growth and developmental activities such as buildings, road construction, change in its planned land use and many other anthropogenic activities for the last three decades which resulted change in its natural environment and city morphology. The study highlighted that GIS and remote sensing techniques are very effective tools to evaluate the dynamics of vegetation cover.' It is clear from the above study that vegetation cover of the study area show significant variations during 1992 to 2015. The results demonstrated that vegetation of the city experienced rapid decrease in almost all the directions. It is noted that expansion of urban area has an impact on surrounding agricultural lands, water and climate. Agricultural land was under great pressure of urban expansion which reduced from $32.6 \%$ in 1992 to $25.1 \%$ in 2015 and showed tremendous changes $\left(111 \mathrm{~km}^{2}\right)$ during the 24 years. The study noted that several problems arise due to vegetation loss in urban environment. Therefore it is suggested that separate detail studies should be taken on these problems after regular time periods by city planners, local engineers and urban planners for sustainable urban and regional planning. 


\section{References}

Alsaaideh, B., Hanbali, A., \& Tateishi, R. (2011). Assessment of land use / cover change and urban expansion of central part of Jordan using Remote Sensing and GIS. Asian Journal of Geoinformatics, 2(3).

Arulbalaji, P., \& Gurugnanam, B. (2014). Evaluating The Normalized Difference Vegetation Index Using Landsat Data By ENVI In Salem District, Tamilnadu, INDIA. International journal of Development Research, 4 (9),1844-1846.

Bhalli, M.N., Ghaffar, A., Shirazi, S.A., \& Parveen, N. (2013). Use of Multi Temporal Digital data to Monitor LULC Changes in Faisalabad-Pakistan. Pakistan Journal of Science, 65(1), 58- 6.

Ellis, E., \& Pontius, JR.RG. (2006). Land use and Land Cover Change, Encyclopedia of Earth. Available at http: //www.eoearth:org/article/landuse and land cover change.

Govt of Pakistan. (1999). District Census Report of Sargodha 1998. Islamabad: Population Census Organization, Statistics Division.

Jensen, J. (2005). Introductory Digital Image Processing A Remote Sensing Perspective. (3 $3^{\text {td }}$ ed.). Upper Saddle River, NJ, USA: Pearson Prentice Hall.

Khalid, M. (2013). Impact of Urban Expansion on Land use changes of Sargodha City, 1992 - 2010. (Unpublished M.Phil thesis). University of Sargodha, Sargodha.

Lillesened, T.M., Kiafer, R.W., \& Chipnan, J.W. (2004). Remote Sensing and Image Interpretation.(5 ${ }^{\text {th }}$ ed.). John Wiley \& Sons, New York, U.S.A.

Marriappan, V.E., Naganani, K., \& Manaharen, N. (2010). Multi Temporal Land use / Land cover Change Detection in some Urban Vellore District using Landsat TM \& ETM+ Data. International Journal of Applied Bioengineering, 4 (2), 1 - 6.

Matteucci, S.D., Morello, J. (2009). Environmental consequences of exurban expansion in an agricultural area: the case of the Argentinian Pampas ecoregion. Urban Ecosyst 12, 287-310.

Peres, C. \& Terborgh, J. (1995). Amazonian Nature Reserves: An Analysis of the Defensibility Status of Existing Conservation Units and Design Criteria for the Future.Conservation Biol. 9, 34- 46.

Rehman, A., Kumar, S., Fazal, S., \& Siddiqui, M.A. (2010). Assessment of Land use / Land cover Change in North - West District of Delhi using Remote Sensing and GIS Techniques. Indian society of Remote Sensing, $1-9$.

Riaz, O., Ghaffar,A., and Butt, I. (2014). Modelling Land Use Patterns of Lahore (Pakistan) using Remote Sensing and GIS. Global Journal of Science Frontier Research. Environment \& Earth Science, 14(1), 24-30.

Rimal, B. (2011). Urban Growth and Land use /Land cover Change of Biratnager Sub Metropolitan City, Nepal. Applied Remote Sensing Journal, 2 (1), 6 - 15.

Sultana, S., \& Marzen, L. (2004). Quantifying Urban Encroachment in Dhaka, Bangladesh from 1989-2000. Paper presented at Applied Geography Conferences, St. Louis, USA.

United Nations, (2011). World Population Prospects and World Urbanization Prospects. New York: Population Division, Department of Economics and Social Affairs, United Nations.

United Nations, (2014). World Population Prospects and World Urbanization Prospects. New York: Population Division, Department of Economics and Social Affairs, United Nations. 